The Brazilian Popular Restaurant Program: a user's profile-oriented approach. Abadio Finco e Finco

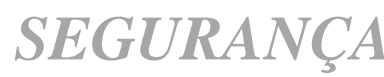

alimentar e nutricional

\title{
The Brazilian Popular Restaurant Program as an integrated action for food security and health promotion: a user's profile-oriented approach
}

\author{
Fernanda Dias Bartolomeu Abadio Finco ${ }^{1}$ e Marcus Vinicius Alves Finco ${ }^{2}$
}

The Brazilian Popular Restaurant Program is a food security and nutrition action. O Program targets those who are considered the most vulnerable people, especially regarding socioeconomics and health conditions. The research aimed at assessing the Brazilian Popular Restaurant Program as an integrated action for food security and health based on a user's profile-oriented approach. A cross-section survey was conducted in 2007 in PalmasTO, Northern Brazil. Socioeconomic variables, food consumption and health conditions of the popular restaurants' users were evaluated by questionnaire. Anthropometric measurements (height and weight) were also collected by trained researchers. A total of 600 users of the two units of the Popular Restaurant Programme in Palmas TO, Brazil, participated voluntarily to the study. Socioeconomic data describes that not all users fulfill the financial requirements to benefit from the program. A food pattern of users comprises a low fruit and vegetables consumption. Health and nutritional data indicates a relevant number of the users with monotonous diet and low physical activity level. The results point out that the Program needs to be improved specifically regarding development of health promotion towards the prevention of non-communicable diseases.

Key-words: collective feeding, food security and nutrition, health promotion, public policy.

\section{O Programa Restaurante Popular Brasileiro como uma ação integrada de segurança alimentar e promoção da saúde: uma abordagem orientada no perfil do usuário}

O Programa Brasileiro de Restaurante Popular é uma ação de segurança alimentar e nutricional. O Programa pretende atingir aqueles que são considerados os mais vulneráveis, especialmente em relação aos apectos socioeconômicos e condições de saúde. A pesquisa teve por objetivo avaliar o Programa de Restaurante Popular Brasileiro como uma ação integrada para a segurança alimentar e saúde com abordagem orientada no perfil do usuário. Um estudo transversal foi realizado em 2007 em Palmas-TO, Norte do Brasil. Variáveis socioeconômicas, consumo de alimentos e condições de saúde dos usuários dos restaurantes populares foram avaliados por questionário. Medidas antropométricas (peso e altura) também foram coletadas por pesquisadores treinados. Um total de 600 usuários das duas unidades do Programa Restaurante Popular em Palmas, participaram voluntariamente do estudo. Dados socioeconômicos descrevem que nem todos os usuários preenchem os requisitos financeiros estabelecidos pelas normas do programa. O padrão alimentar dos usuários é composto por baixo consumo de frutas e legumes. Dados nutricionais e de saúde indicam um número relevante dos usuários com uma dieta monótona e também baixo nível de atividade física. Os resultados apontam a necessidade de aperfeiçoamento do Programa, especificamente às questões relacionadas ao desenvolvimento de ações de promoção da saúde e prevenção de doenças crônicas não transmissíveis.

Palavras-chave: alimentação coletiva, segurança alimentar e nutricional, promoção da saúde, políticas públicas.

\footnotetext{
${ }^{1}$ Docente, Laboratório de Segurança Alimentar e Nutricional (LabSAN), Universidade Federal do Tocantins (UFT). Correspondência: Av. NS 15, ALC NO 14, 109 Norte, CEP 77000-000, UFT, Palmas, TO. E-mail: fabadio@gmail.com.

${ }^{2}$ Docente, LabSAN, UFT.
} 
The Brazilian Popular Restaurant Program: a user’s profile-oriented approach. Abadio Finco e Finco

\section{INTRODUCTION}

Apart from the fact that Brazil is one of the biggest food producers in the world, a significant part of the Brazilian population does not have stable access to food daily. Situations of food and nutritional insecurity are illustrated from a variety of problems such as: hunger, obesity, malnutrition diseases, consumption of unhealthy food from doubtful sources, social and economic relations, environmental degradation from food production, unethical prices for necessities and the imposition of food patterns that do not take into account cultural diversity.

The poorest people are deprived of access to high quality food, to the required equipment to conserve and prepare meals in a good manner and also have less access to information about healthy and adequate food. In this context, the government should promote and execute policies towards aiming to guarantee good quality food for those who cannot obtain it with their own resources, including policies that promote discussion of Food and Nutrition Security (FNS) throughout the country.

In Brazil, food nutrition and security is defined as a person's right to access good quality food in sufficient quantity, regularly and permanently without compromising other essential needs based on nutritional practices for health promotion and in respect to cultural diversity and sustainable economic, social and environmental standards [1,2].

With the aim of targeting the precepts of food and nutrition security, the Brazilian federal government has begun fostering public policies that seek to satisfy food deficits of the most vulnerable population within the country. According to this strategy, these policies must include efforts, not just from government side, but also, and especially, from the side of civil society. And for this reason, these policies should integrate multiple governmental sectors, such as: health, education, work, agriculture, social development, environment, and economy, as well as different spheres such as: production, commercialization, quality control, access, and consumption. Based on this, the Brazilian Popular Restaurant Program - which aims to target predominately low-income people who live in urban areas - is an action included among those within the national Brazilian FNS policy. Above all, the Program is a policy that seeks to generate a food protection net in areas in which a large amount of the people eat their meals outside of their home and in this way reaching the most vulnerable people.

Due to budget restrictions, a significant part of the Brazilian population does not have access to the traditional market of ready meals. Many workers whom receive food stamps from the government or private companies prefer to use them to purchase in natura food in supermarkets, for instance. However, in most cases, these workers live in areas far away from the work place and, therefore, face high transportation costs to have a meal. In addition, these workers are often not able to afford traditional meals, resulting in the consumption of a packed lunch from home (socalled marmita) as a solution for lunch due to a lack of money and time. This is the situation that violates healthy food habits daily, compromising meal quality and increasing health risks, since these pan meals do not have the features that fulfill the prerequisites of an adequate meal e.g. food safety.

From a health and FNS standpoint, the popular restaurants should offer ready meals, respecting requisites, such as quality, promotion of good eating habits and nutritional education, keeping the equilibrium between the nutrients of a single meal and, therefore, decreasing the figures of people facing food insecurity conditions and health problems. This requires also, in a FNS context, that the meal should have a high hygienic-sanitary quality, which would then prevent foodborne diseases and, therefore, guarantee population health. Based on this, meals offered by popular restaurants should originate from quality controlled environments and in conformity with sanitary surveillance guidelines for food services.

Aiming to reach maximum efficiency, the Program presents some pre-requisites for the implementation of a popular restaurant, for example: the target group should be a part of the population that faces food insecurity and has a low income, i.e. those who are considered the most vulnerable. In this context, the major part of popular restaurant users should be composed of people who cannot afford a ready meal in a private restaurant and, therefore, need governmental subsidy to have a quality meal.

\section{The Popular Restaurants in the city of Palmas, Northern Brazil}


The Brazilian Popular Restaurant Program: a user’s profile-oriented approach. Abadio Finco e Finco

Palmas is a city located in the state of Tocantins in Northern Brazil, in a region so-called Brazilian Legal Amazon Region. There are two popular restaurants, implemented in 2004. One is located in the center of the city and the other in the suburb, named Taquaralto. On average, both restaurants offer 2000 ready meals per day and both are outsourced. The restaurant menu includes four preparations (salad, and a protein dish based on meat, rice and beans) daily. The ready meals are served during lunch-time (11:00 to 13:00) and seek to complement or supplement a considerable part of the populations daily nutrition needs.

Recently, both popular restaurants have been a topic of discussion throughout Tocantins. The Tocantins' Council for Food Security and Nutrition (CONSEA/TO) have discussed the popular restaurants in many of their regular meetings and some questions were raised towards the non-fulfillment of many requisites e.g. economic profile of users. However, as there were no scientific data available to support the regarded allegations the discussion could not be concluded.

Based on the facts mentioned above, it is imperative that a scientific study on the Program of popular restaurants would had been carried out in the city of Palmas, focusing on food security, nutrition and health aspects. Thus, the objective of this research is to collect primary data that aims to support the discussions concerning this Program in the city of Palmas, especially towards the integration of health and food security actions.

\section{METHODOLOGICAL ASPECTS}

The socioeconomic and nutritional data was collected among the popular restaurants users and was carried out in 2007. A specific questionnaire was used to collect all the information needed, both to draw the users' profile.

\section{Data collection}

The data collection was made through a cross-sectional survey, which comprised specific questionnaires with closed, as well as open-ended, questions [3]. After the questionnaire design, a pilot study was carried out with 40 non-users of popular restaurants, with the goal of checking the ability of participants to understand the questions. During the research period 600 questionnaires were applied in both popular restaurants, Central and Taquaralto (300 questionnaires in each restaurant). The users were selected randomly and participated spontaneously and voluntarily. Questionnaires were applied within at least 3-minute intervals, excluding those younger than 18 years old and those who did not want to participate in the study.

In the first part of the questionnaire socioeconomic and health data were collected. Aiming at depicting the food pattern of the restaurants' users, the dietetic assessment was done using a consumption frequency questionnaire validated by Ribeiro et al. [4]. The food consumption was specified based on weekly frequency and the consumption of each food was quantified, receiving the weights presented in Table 1. The codification used in the research was adapted from those used by Liu et al. [5].

Simultaneously, anthropometric data was collected (height and weight). After that the Body Mass Index (BMI) was estimated, considering the rate between body weight and height squared $\left(\mathrm{kg} / \mathrm{m}^{2}\right)$. The height was determined with a portable height meter (Brand: Altura exata) with a scale of $0.1 \mathrm{~cm}$. The body weight was determined with anthropometric digital equipment with $100 \mathrm{~g}$ precision, according to the method presented by Gordon et al. [6]. The BMI results were validated based on the international classification of the World Health Organization (WHO) regarding overweight (BMI $>25 \mathrm{~kg} / \mathrm{m}^{2}$ ) and obesity (BMI $>30$ $\mathrm{kg} / \mathrm{m}^{2}$ ). The limits used to measure the level of physical activity were based on international limits suggested by Food and Agriculture Organization (FAO) [7].

All data (socioeconomic, health, and anthropometric) was collected by researchers previously trained to operate the equipment. The people interviewed were invited to join the research, voluntarily, and their identity was kept anonymous.

\section{Statistical analysis}

After the field survey, the data was transferred from the questionnaires into a Microsoft Excel worksheet as a data base file. The data was then separated into several sub-topics, for example person identification, socioeconomic and health conditions, etc. With the data bank in place, Box and Whisker Plots were used as a detection method for outliers in 
The Brazilian Popular Restaurant Program: a user's profile-oriented approach. Abadio Finco e Finco

Table 1. Codification of weekly food consumption.

\begin{tabular}{ccccccc}
\hline $\begin{array}{c}\text { No } \\
\text { consumption }\end{array}$ & $\begin{array}{c}\mathbf{1} \text { to } \mathbf{3} \\
\text { times/month }\end{array}$ & $\begin{array}{c}\text { Once } \\
\text { a week }\end{array}$ & $\begin{array}{c}\mathbf{2} \text { to } 4 \\
\text { times/week }\end{array}$ & $\begin{array}{c}\mathbf{5} \text { to } \mathbf{6} \\
\text { times/week }\end{array}$ & $\begin{array}{c}\text { Once } \\
\text { a day }\end{array}$ & $\begin{array}{c}\mathbf{2} \text { or more } \\
\text { times/day }\end{array}$ \\
\hline 0 & 0 & 1 & 3,0 & 5,5 & 7 & 14 \\
\hline Source: adapted from Liu et al. [5]. & & & &
\end{tabular}

quantitative data. Extreme values, wrong answers and mistakes in data entry were addressed and all missing values were replaced by the arithmetic means.

The socioeconomic analysis involves statistical methods utilizing exploratory and descriptive data analysis. Continuous variables were presented with mean values and their respective standard error. The distribution similarities were checked through the Kolmogorov-Smirnov test. Association among categorical variables was checked by Chi-square test $\left(\chi^{2}\right)$, whereas $t$-student and Mann-Whitney $U$ tests were used for symmetric and asymmetric distributions, respectively. The Kruskal-Wallis test was applied using the Dunn procedure in sequence, aiming at verifying differences among non-parametric distribution means. The statistical tests were completed using the software XLStat.

\section{RESULTS}

\section{Socioeconomic profile of popular restaurants' users}

The results regarding the socioeconomic profile of popular restaurants' users in both popular restaurants (Central and Taquaralto) are presented in Table 2.

The age of respondents ranged from 18 to 69 years for the Central popular restaurant, and from 18 to 74 years for the popular restaurant in Taquaralto, showing the presence of both young and old people among the users. However, when considering the average age of users, we found the predominance of young people as users of services offered at both restaurants, 24 years for the Central and 32 years of age for Taquaralto. There was no significant difference in the mean age variable between the two restaurants studied $(p>0.05)$.

Regarding educational level of users for the Central popular restaurant, we found that $43 \%$ of users had completed secondary level, followed by $22 \%$ who had not completed secondary level. Along with those who had completed higher education $(6 \%)$, we found that $71 \%$ of users to the Central popular restaurant had a level of education above a secondary degree. Regarding gender, it was found that the vast majority of respondents was male, $77 \%$, and $23 \%$ were female. When exploring the data for the popular restaurant in Taquaralto, we found that $28 \%$ of users had completed secondary level, followed by $22 \%$ who had completed basic level. Approximately $4 \%$ of respondents had no schooling and, therefore, are considered illiterate. Regarding gender, we found that most were men ( $71 \%$ of users), compared to only $29 \%$ of women. The education variable showed significant differences when comparing both restaurants $(p<$ $0.05)$, while the gender variable displayed similar trends in both locales.

The variable income per capita was employed, making the conversion of individual income divided by the number of people who enjoy or depend on this income (dependents) per month. So, after data collection this variable was split into different values aiming at making it clear and succinct for later analysis. The separation was performed in strata of $\mathrm{R} \$ 100.00$ (Brazilian Real) in order to better understand the user's purchasing power. It was found that the total monthly income per capita has a great variability among users, ranging from a minimum of $\mathrm{R} \$ 0.00$ to a maximum of $\mathrm{R} \$ 3000.00$ for the Central popular restaurant. The maximum value is significant compared to the average value declared by the 300 respondents, which was $\mathrm{R} \$ 334.37$ per capita per month, with a standard deviation of $\mathrm{R} \$ 379.35$. For the Taquaralto popular restaurant, the total monthly income per capita also showed a large variability between users, ranging froma minimum of $\mathrm{R} \$ 0.00$ up to a maximum of $\mathrm{R} \$ 2000.00$. The maximum value is significant compared to the average of the 300 respondents, which was $\mathrm{R} \$ 356.97$ per capita per month, with a standard deviation of $\mathrm{R} \$ 380.56$. The values of $\mathrm{R} \$ 0.00$ per capita per month represent the responses of 
The Brazilian Popular Restaurant Program: a user’s profile-oriented approach. Abadio Finco e Finco

Table 2. Socioeconomic profile of popular restaurants' users, Palmas/TO.

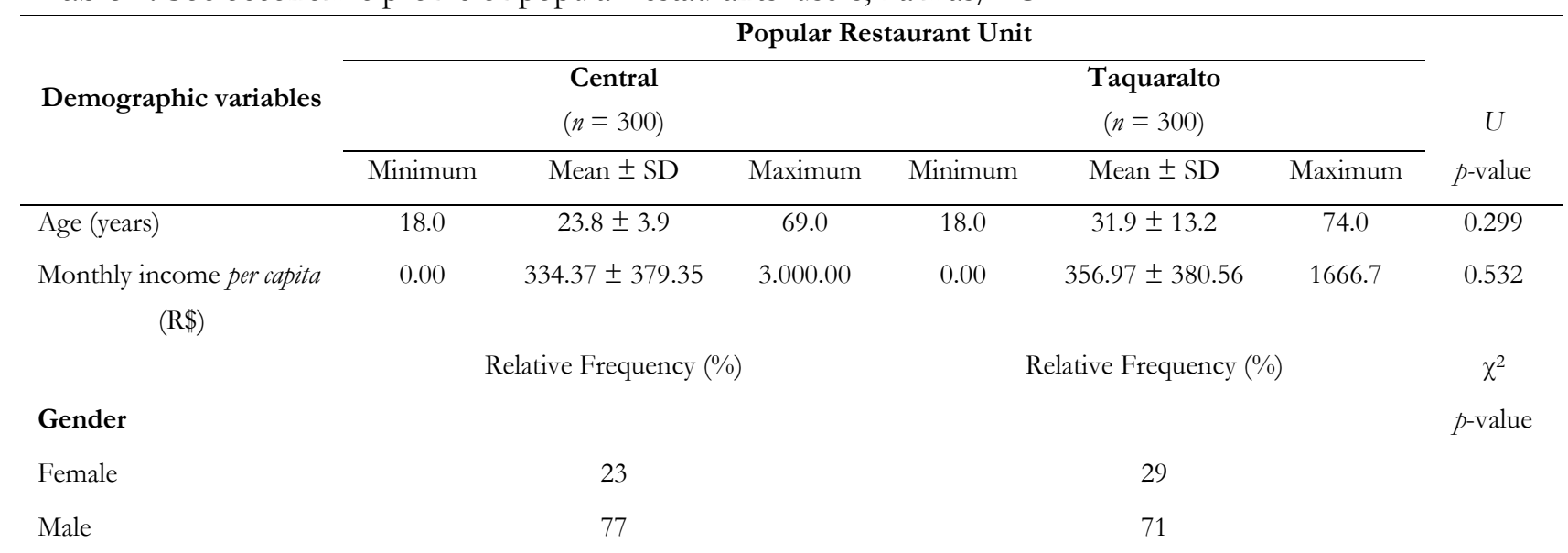

\section{Monthly income per capita $(\mathrm{R} \$)$}

$\mathrm{R} \$ 100$ to $\mathrm{R} \$ 199$

$\mathrm{R} \$ 200$ to $\mathrm{R} \$ 299$

$\mathrm{R} \$ 300$ to $\mathrm{R} \$ 399$

$\mathrm{R} \$ 400$ to $\mathrm{R} \$ 499$

$\mathrm{R} \$ 500$ to $\mathrm{R} \$ 599$

$\mathrm{R} \$ 600$ to $\mathrm{R} \$ 699$

$\mathrm{R} \$ 700$ to $\mathrm{R} \$ 799$

$\mathrm{R} \$ 800$ to $\mathrm{R} \$ 899$

$\mathrm{R} \$ 900$ to $\mathrm{R} \$ 999$

$\mathrm{R} \$ 1000$ to $\mathrm{R} \$ 1199$

$\mathrm{R} \$ 1200$ to $\mathrm{R} \$ 1499$

$\mathrm{R} \$ 1500$ to $\mathrm{R} \$ 1999$

above $\mathrm{R} \$ 2000$

\section{Education}

None 2

Primary level incomplete $\quad 10$

4

Primary level complete

Secondary level

Secondary level complete

High education

High education complete

Post-Graduate degree

0

4

1

Source: research results (2007). Note: SD = Standard Deviation. 
students who claimed not to have any income at the time the survey was carried out. Unemployed people have also stated this value as their income level. These users have been kept in the analysis and the discussion about users of popular restaurants since such individuals fulfill the main asset in question, i.e. vulnerability. Measures of variability and trend were also calculated with the absence of these users in order to compare their results with the overall outcome, but the measurements were not significantly different (mean, standard deviation) compared to the total sample. Among the socioeconomic variables, income is the one that had the most variability, being the only one that showed a coefficient of variation $(\mathrm{CV}=$ standard deviation/mean) greater than one, indicating the diversity on income per capita of popular restaurant users.

After stratification of income, we found that $22 \%$ of respondents in the Central popular restaurant had monthly income per capita up to $\mathrm{R} \$ 99.00$, followed by $17 \%$ who had monthly income per capita within the range from $\mathrm{R} \$ 100.00$ to $\mathrm{R} \$ 199.00$, resulting in a total of $39 \%$ of users in a situation of low income per capita, according to the Federal Decree No. 6135 of June 26, 2007 , which considers a low-income family to be one with an income per capita up to half of the minimum salary, monthly ${ }^{3}$. Similar trends can be observed for the popular restaurant of Taquaralto where we found that $24 \%$ of respondents had a monthly income per capita of up to $\mathrm{R} \$ 99.00$, followed by $15 \%$ who had a monthly income per capita within the range from $\mathrm{R} \$ 100.00$ to $\mathrm{R} \$ 199.00$, resulting in a total of $39 \%$ of users in a situation of low income per capita [8]. However, $69 \%$ of users had a family income per capita of up to $\mathrm{R} \$ 399.00$, i.e. a value close to the minimum salary ( $\mathrm{R} \$ 380.00)$, suggesting that most users of both popular restaurants are susceptible to budget constraints in respect to economic access to quality food.

\section{Health characteristics}

Results regarding the health characteristics of popular restaurants' users for each restaurant are presented in Table 3. We found, for instance, that in the Central popular restaurant $61.7 \%$ of users showed normal weight and $6.7 \%$ were considered underweight. However, it draws attention to the fact

\footnotetext{
${ }^{3}$ The minimum salary, during the time the research was carried out, was $\mathrm{R} \$ 380.00$ (BRASIL, 2007) [11]. One Brazilian real (R\$1.00) is equivalent to a US\$0.5 (BANCO CENTRAL DO BRASIL, 2010).
}

that $24.3 \%$ of the users of this popular restaurant were overweight and $7.3 \%$ were classified as obese. A similar trend was found for popular restaurant of Taquaralto where $63 \%$ of users were normal weight and $2.4 \%$ underweight. Approximately $27 \%$ of users surveyed at this restaurant were overweight and $7.7 \%$ were within the range of BMI defined as obesity.

When inquired about physical activity, $78 \%$ of users of the Central popular restaurant practiced mild physical activity, followed by $18 \%$ who reported moderate practice, and 4\% who reported intense physical activity. Again a similar trend was found for Taquaralto popular restaurant, where $80 \%$ of respondents reported physical activity as mild, 13\% moderately, and 7\% intense activity. In both popular restaurants (Central and Taquaralto) approximately $20 \%$ of the population reported having at least one of the asked Chronic Non Communicable Diseases (NCDs) (cardiovascular disease, diabetes, cancer). Araújo et al. ["] found a similar result where $19.6 \%$ of users of a popular restaurant in Fortaleza/CE (northeast region of the country) suffered from chronic diseases.

\section{Dietary assessment}

The Food Frequency Questionnaire (FFQ) is the most widely method used for measuring past diet, specifically due to its ability to classify individuals according to their usual eating patterns, besides also being an easy management tool and inexpensive, therefore, enabling its usage in population studies [10].

The results obtained by the FFQ represent the food consumption practiced by users in their usual diets. A quantitative approach of food consumption is presented in Table 4, which contains a comparison of the average consumption of the same food in the two popular restaurants reflecting the food patterns practiced by users in their daily lives ( $p$-value) and the analysis of the average consumption of foods from the same group for users of each popular restaurant.

By observing the group dairy products only consumption of whole milk products showed a significant difference between the mean values. The Taquaralto popular restaurant showed lower values for this product, indicating that users from this restaurant consume less whole milk on their usual diets. However, despite the difference in consumption, whole milk was the most consumed food in the two 
Table 3. Health characteristics of popular restaurants' users.

\section{Popular Restaurant Unit}

\begin{tabular}{|c|c|c|c|c|c|c|c|}
\hline \multirow{4}{*}{ Health Characteristics } & \multirow{3}{*}{\multicolumn{3}{|c|}{$\begin{array}{l}\text { Central } \\
(n=300)\end{array}$}} & \multirow{3}{*}{\multicolumn{3}{|c|}{$\begin{array}{c}\text { Taquaralto } \\
(n=300)\end{array}$}} & \multirow{4}{*}{$\begin{array}{c}U \\
p \text {-value }\end{array}$} \\
\hline & & & & & & & \\
\hline & & & & & & & \\
\hline & Minimum & Mean \pm SD & Maximum & Minimum & Mean \pm SD & Maximum & \\
\hline \multirow[t]{2}{*}{ BMI $\left(\mathrm{kg} / \mathrm{m}^{2}\right)$} & 15.6 & $23.8 \pm 3.9$ & 39.6 & 16.7 & $24.0 \pm 3.8$ & 40.7 & 0.507 \\
\hline & \multicolumn{3}{|c|}{ Relative frequency $(\%)$} & \multicolumn{3}{|c|}{ Relative frequency $(\%)$} & $x^{2}$ \\
\hline \multicolumn{4}{|l|}{ Nutritional status (BMI) } & & & & $p$-value \\
\hline Underweight & \multicolumn{3}{|c|}{6.7} & \multicolumn{3}{|c|}{2.4} & 0.086 \\
\hline Eutrophic & \multicolumn{3}{|c|}{61.7} & \multicolumn{3}{|c|}{63.0} & \\
\hline Overweight & \multicolumn{3}{|c|}{24.3} & \multicolumn{3}{|c|}{26.9} & \\
\hline Obese & \multicolumn{3}{|c|}{7.3} & \multicolumn{3}{|c|}{7.7} & \\
\hline \multicolumn{8}{|l|}{ Physical activity level } \\
\hline Mild & \multicolumn{3}{|c|}{78} & \multicolumn{3}{|c|}{80} & 0.025 \\
\hline Moderate & \multicolumn{3}{|c|}{18} & \multicolumn{3}{|c|}{13} & \\
\hline Intense & \multicolumn{3}{|c|}{4} & \multicolumn{3}{|c|}{7} & \\
\hline
\end{tabular}

Source: research results (2007). Note: SD = Standard Deviation.

restaurants with regards to the dairy group, differing significantly from other products in this group.

In the meat and egg group, which presumably indicates the main source of animal protein diet, beef was the food with the highest frequency of consumption, differing significantly from all other foods in this group and may be considered a food consumed daily among users of both popular restaurants. Chicken and fried eggs were also foods with higher average consumption. Nevertheless, the consumption of these foods can be considered low, approximately twice a week.

Margarine was the most consumed food among the oil group, differing significantly from the others. Between the consumption of cereals and legumes, beans were the item with the highest daily consumption for both restaurants, followed by rice and French bread. In relation to consumption of fruits and vegetables, we observed that the consumption is low in the two restaurants because the highest consumption is approximately 3 times per week for raw leaf and fruit. Candy proved not to be widely consumed, however, daily consumption of sugary drinks was observed, within this sub-group coffee with sugar had the highest value, about 6 times per week, for both popular restaurants.

From the quantitative analysis of food consumption, foods were grouped according to their values of relative frequency of consumption $(0<1=$ no consumption; $\geq 1$ to $<3=$ once a week; $\geq 3$ to $<5.5$ $=2$ to 4 times a week; $\geq 5.5-7=5$ to 6 times a week; $\geq 7$ to $<14=$ once a day; $14=2$ or more times a day). As a result, this classification provided the food pattern of the restaurants' users as described in Table 5: 
The Brazilian Popular Restaurant Program: a user’s profile-oriented approach. Abadio Finco e Finco

Table 4. Quantitative analysis of weekly frequency of food consumption from restaurants' users.

\begin{tabular}{|c|c|c|c|}
\hline \multirow{3}{*}{ Food groups } & \multicolumn{2}{|c|}{ Popular restaurant \# } & \multirow[b]{3}{*}{$p$-value } \\
\hline & $\begin{array}{c}\text { Central } \\
(n=300)\end{array}$ & $\begin{array}{c}\text { Taquaralto } \\
(n=300)\end{array}$ & \\
\hline & Mean & Mean & \\
\hline \multicolumn{4}{|l|}{ Dairy food } \\
\hline Skimmed milk & $1.32^{\mathrm{ab}}$ & $1.30^{\mathrm{a}}$ & $0.474^{*}$ \\
\hline Whole milk & $4.85^{c}$ & $3.55^{\mathrm{ab}}$ & 0.002 \\
\hline Yogurt & $0.93^{\mathrm{b}}$ & $1.34^{\mathrm{b}}$ & $0.084^{*}$ \\
\hline White cheese ("minas frescal" type) & $0.99 \mathrm{~b}$ & $1.00^{\mathrm{b}}$ & $0.836^{*}$ \\
\hline Yellow cheese ("prato" type) & $1.32^{\mathrm{b}}$ & $0.94 \mathrm{~b}$ & $0.047^{*}$ \\
\hline Cream cheese & $0.38^{\mathrm{a}}$ & $0.33^{\mathrm{a}}$ & $0.744^{*}$ \\
\hline \multicolumn{4}{|l|}{ Meat and eggs } \\
\hline Fried egg & $1.82^{\mathrm{d}}$ & $1.70^{\mathrm{d}}$ & $0.520^{*}$ \\
\hline Boiled egg & $0.88^{\mathrm{bc}}$ & $0.91^{\mathrm{bc}}$ & $0.508^{*}$ \\
\hline Beef & $7.29 \mathrm{f}$ & $6.64 \mathrm{e}$ & 0.040 \\
\hline Pork & $0.48^{\mathrm{ab}}$ & $0.60^{\mathrm{ab}}$ & $0.637^{*}$ \\
\hline Chicken & $2.07 \mathrm{e}$ & $1.92^{\mathrm{d}}$ & $0.164^{*}$ \\
\hline Fish & $0.50^{\mathrm{bc}}$ & $0.83^{\mathrm{bc}}$ & 0.033 \\
\hline Canned fish (sardine/tune fish) & $0.16^{\mathrm{a}}$ & $0.16^{a}$ & $0.620^{*}$ \\
\hline Sausages, ham, salami & $1.24 \mathrm{~cd}$ & $0.98^{c}$ & $0.274^{*}$ \\
\hline Salted meat (cod fish, jerked beef) & $0.47 \mathrm{ab}$ & $0.75^{\mathrm{bc}}$ & $0.001^{*}$ \\
\hline Liver, kidney, heart & $0.35^{\mathrm{ab}}$ & $0.60^{\mathrm{bc}}$ & 0.010 \\
\hline \multicolumn{4}{|l|}{ Oils } \\
\hline Olive oil & $0.94^{a}$ & $0.80^{\mathrm{a}}$ & $0.389^{*}$ \\
\hline Salad dressings & $0.62^{\mathrm{a}}$ & $0.60^{\mathrm{a}}$ & $0.569^{*}$ \\
\hline Bacon & $0.47 \mathrm{a}$ & $0.38^{a}$ & $0.952^{*}$ \\
\hline Butter & $1.75^{\mathrm{ab}}$ & $1.19^{\mathrm{ab}}$ & $0.302^{*}$ \\
\hline Margarine & $4.34^{c}$ & $3.43^{c}$ & 0.027 \\
\hline Mayonnaise & $1.32^{\mathrm{b}}$ & $0.91^{\text {a }}$ & 0.028 \\
\hline \multicolumn{4}{|l|}{ Snacks } \\
\hline Chips, sandwich, pizza, pastries, peanuts & 1.19 & 1.280 & $0.610^{*}$ \\
\hline Canned food (maize, green beans, palm heart, olive) & 1.03 & 1.045 & $0.296^{*}$ \\
\hline \multicolumn{4}{|l|}{ Cereals/Beans } \\
\hline Rice & $6.58^{a}$ & $5.62^{\mathrm{de}}$ & 0.017 \\
\hline Bread & $4.97 \mathrm{~d}$ & $3.97 \mathrm{e}$ & 0.009 \\
\hline Whole bread & $0.51^{\mathrm{a}}$ & $0.80^{\mathrm{a}}$ & 0.008 \\
\hline Salted cookies & $2.16^{\mathrm{bc}}$ & $1.92^{\mathrm{bc}}$ & $0.753^{*}$ \\
\hline Sweet cookies & $1.43^{\mathrm{b}}$ & $1.38^{\mathrm{b}}$ & $0.819^{*}$ \\
\hline Cakes & $1.22^{\mathrm{b}}$ & $1.77 \mathrm{bc}$ & 0.006 \\
\hline Pasta/noodles & $2.07 \mathrm{c}$ & $2.20 \mathrm{~cd}$ & $0.975^{*}$ \\
\hline Beans & $8.72^{\mathrm{e}}$ & $9.69^{\mathrm{f}}$ & 0.007 \\
\hline
\end{tabular}


Table 4. Continuation

\begin{tabular}{|c|c|c|c|}
\hline \multirow{3}{*}{ Food groups } & \multicolumn{2}{|c|}{ Popular restaurant \# } & \multirow[b]{3}{*}{$p$-value } \\
\hline & $\begin{array}{l}\text { Central } \\
(n=300)\end{array}$ & $\begin{array}{l}\text { Taquaralto } \\
(n=300)\end{array}$ & \\
\hline & Mean & Mean & \\
\hline \multicolumn{4}{|l|}{ Vegetables/Fruits } \\
\hline Raw leaves & $3.33^{\mathrm{c}}$ & $2.84^{\mathrm{c}}$ & $0.174^{*}$ \\
\hline Cooked leaves & $0.91^{\mathrm{a}}$ & $1.01^{\mathrm{a}}$ & $0.267^{*}$ \\
\hline Raw vegetables & $3.43^{c}$ & $3.18^{c}$ & $0.429^{*}$ \\
\hline Cooked vegetables & $1.85^{\mathrm{b}}$ & $1.70^{\mathrm{b}}$ & $0.424^{*}$ \\
\hline Roots (cará, cassava, potato, yam) & $1.45^{\mathrm{b}}$ & $1.91^{\mathrm{b}}$ & 0.030 \\
\hline Fruits & $3.41^{\mathrm{c}}$ & $3.71^{\mathrm{d}}$ & $0.077^{*}$ \\
\hline \multicolumn{4}{|l|}{ Desserts/Sweets } \\
\hline Ice cream & $0.71^{b}$ & $0.93 \mathrm{bc}$ & $0.514^{*}$ \\
\hline Pie & $0.15^{\mathrm{a}}$ & $0.16^{\mathrm{a}}$ & $0.811^{*}$ \\
\hline Jam & $0.08^{\mathrm{a}}$ & $0.10^{\mathrm{a}}$ & $0.987^{*}$ \\
\hline Sweets/candies & $2.84^{c}$ & $2.19 \mathrm{c}$ & 0.041 \\
\hline Chocolate & $1.53^{\mathrm{b}}$ & $0.82^{\mathrm{b}}$ & 0.001 \\
\hline \multicolumn{4}{|l|}{ Beverages } \\
\hline Coffee without sugar & $0.51^{\mathrm{a}}$ & $0.57^{\mathrm{a}}$ & $0.336^{*}$ \\
\hline Coffee with sugar & $6.04 \mathrm{~d}$ & $6.13^{c}$ & $0.967^{*}$ \\
\hline Natural fruit juice with sugar & $4.45^{\mathrm{cd}}$ & $3.87 \mathrm{bc}$ & $0.057^{*}$ \\
\hline Natural fruit juice without sugar & $0.76^{\mathrm{a}}$ & $0.62^{a}$ & $0.622^{*}$ \\
\hline Industrialized fruit juice with sugar & $2.16^{\mathrm{b}}$ & $3.06^{\mathrm{b}}$ & 0.011 \\
\hline Industrialized fruit juice without sugar & $0.39 \mathrm{a}$ & $0.28^{a}$ & $0.424^{*}$ \\
\hline Soft drinks & $3.18^{c}$ & $3.07 \mathrm{~b}$ & $0.280^{*}$ \\
\hline
\end{tabular}

Source: research results (2007). Notes: * means non-significant at $5 \%$ level, between rows, i.e. between popular restaurant units. \# Different letters show significant statistical differences in the same column, i.e. between foods from the same group for each popular restaurant unit.

Basically, the food pattern of surveyed people is based on rice, beans and meat as daily food. Coffee is also highly consumed with added sugar. Similarly, fruit juices consumption includes the addition of sugar. It is noteworthy that the consumption of whole milk overweighs skimmed milk.

\section{DISCUSSION}

When the socioeconomic profile of the popular restaurants' users was analyzed, it is interesting to note that less than $40 \%$ of respondents can be classified as low-income users, according to the Federal Decree no 6.135, June 26, 2007, which considers that low-income families are those who present monthly income per capita up to half the minimum salary [11]. We observed that most users of both popular restaurants are in the range below $\mathrm{R} \$$ 399.00 monthly per capita $(69 \%$ in the Central popular restaurant, and also $69 \%$ in the Taquaralto popular restaurant). However, starting from the reference value that classifies a low-income family, the one who has monthly income per capita up to half the minimum salary $(\mathrm{R} \$ 190.00)^{4}$, only $39 \%$ of users of the two restaurants fell into this category. Thus, this result suggests that the Program may not be reaching their maximum effectiveness, regarding their target group. The basic requirement for the implementation of the Program of popular restaurants recommends that a

\footnotetext{
${ }^{4}$ In the present study, from the stratification of the variable income per capita in intervals of $\mathrm{R} \$ 100.00$, we used the value of $\mathrm{R} \$ 199.00$ as the cutoff point for low-income classification.
} 
The Brazilian Popular Restaurant Program: a user’s profile-oriented approach. Abadio Finco e Finco

Table 5. Food pattern of surveyed people based on quantitative analysis.

Central

Taquaralto

\section{No consumption}

Jam, pie, canned fish (sardine/tune fish), liver, kidney, Jam, canned fish (sardine/tune fish), pie, industrialized heart, cream cheese, industrialized fruit juice without fruit juice without sugar, cream cheese, bacon sugar, salted meat (cod fish, jerked beef), bacon, pork

\section{Once a week}

Fish, whole bread, coffee without sugar, salad dressings, ice cream, natural fruit juice without sugar, boiled egg, cooked leaves, yogurt, olive oil, white cheese ("minas frescal' type), canned food (maize, green beans, palm heart, olive), chips, sandwich, pizza, pastries, peanuts, cakes,sausages, ham, salami, skimmed milk, yellow cheese ("prato" type), mayonnaise, sweet cookies, roots (cará, cassava, potato, yam), chocolate, butter, fried egg, cooked vegetables, chicken, pasta/noodles, salted cookies, industrialized fruit juice with sugar
Salad dressings, liver, kidney, heart, pork, coffee without sugar, natural fruit juice without sugar, salted meat (cod fish, jerked beef), olive oil, whole bread, chocolate, fish, boiled egg, mayonnaise, ice cream, yellow cheese ("prato" type), sausages, ham, salami, white cheese ("minas frescal" type), cooked leaves, canned food (maize, green beans, palm heart, olive), butter, chips, sandwich, pizza, pastries, peanuts, skimmed milk, yogurt, sweet cookies, fried egg, cooked vegetables, cakes, roots (cará, cassava, potato, yam), chicken, salted cookies, sweets/candies, pasta/noodles

\section{2 to 4 times a week}

$\begin{aligned} & \text { Sweets/candies, soft drinks, raw leaves, fruits, raw } \\
& \text { vegetables, margarine, natural fruit juice with sugar, } \\
& \text { whole milk, Bread }\end{aligned}$
\begin{tabular}{l} 
natural fruit juice with sugar, bread \\
\hline
\end{tabular}

\section{5-6 times/week}

Coffee with sugar

Rice, Coffee with sugar

\section{Once a Day}

Rice, beef, beans

Beef, beans

popular restaurant should have as a public target people who are in a situation of food insecurity and have a low-income. We believe that data related to the socioeconomic profile of users might be useful to assist managers, as well as government and decision makers, in shifting the Program towards the target audience.

However, as Food and Nutrition Security is not restrictive to the economic aspect, we suggest that the scope of the target audience for the Program should be assessed not only by their income, but also in conjunction with the data of food patterns, health profile and the nutritional situation of restaurant users that came up with the present research.In this sense, data from the nutritional profile of users showed that over $30 \%$ of the sample group was above the threshold for overweight. This data is consistent with the current reality of the Brazilian population, which demonstrates obesity and overweight as major public health problems [12]. Mariath et al. [13] also noted high rates of overweight $(45 \%)$ and obesity $(9.6 \%)$ in a study $(n=1252)$ with individuals who attended a popular restaurant in the state of Santa Catarina in southern Brazil.

Despite the fact that the research of dietary assessment was not performed quantitatively in terms of caloric intake and nutrients, it was still possible to see the food patterns and dietary consumption patterns of the restaurants' users. When grouping food on the basis of the quantitative analysis aforementioned, the food consumption is clearly unfold and depicts a diet poor in fruits and vegetables where coffee with sugar, rice, beans and meat are the predominant food consumed in usual diet of surveyed people. However, having rice and beans as basic food components is an expected result as these two foods culturally define the basic Brazilian diet. Beef and 
The Brazilian Popular Restaurant Program: a user's profile-oriented approach. Abadio Finco e Finco

whole milk proved to be foods of animal origin most present every day.

The negative factor identified within the results was a low consumption of products such as fruits and vegetables. The fruit juice consumption was classified as 2-4 times per week and neither fruits nor vegetables have at least one portion of consumption according to the food patterns found. This profile is far away from those which recommend five portions of fruits and vegetables per day. Indeed, the so-called smoothies (fruit and vegetables blended) bring micronutrients and phytochemicals but don't substitute the whole fruits and vegetables, especially regarding the fiber content. In addition most of users consume natural fruit juices with additional sugar which increases the energetic density of this food. In summary, one should be alerted to the low consumption of fruits and vegetables, which are sources of micronutrients and other non-nutritional compounds extremely important to an individual health (carotenoids, polyphenols and other antioxidants).

Again, one reason for this low fruit and vegetables consumption by surveyed people may be based not only on income, but also on cultural issues and/or lack of information about diet and nutrition. The diet in northern Brazil culturally does not include the consumption of fruits and vegetables, when compared to other regions of Brazil. This is corroborated in a study conducted by the Brazilian Ministry of Health in 2002, where the capitals of Belem and Manaus, both in northern Brazil, had the lowest consumption of fruits and vegetables. Likewise, the study found that foods rich in animal fat (meat and whole milk) are consumed mostly by the population with lower educational levels, similar to results found in this study, where whole milk and meat consumption were consumed mostly by respondents who have a low education. Therefore, the Program of popular restaurants must process the issue of food through nutritional education activities in order to educate users about the importance of having a diversified diet. In addition, workshops could be conducted to demonstrate how one can have a healthy diet from low cost regional foods, or even a different usage of foods, if any. It is important to emphasize that these nutritional education practices should take into account the cultural and environmental aspects covered by the Brazilian FNS policy. Moreover, the consumption of fruits could also be motivated by the inclusion of a portion of fruit in the menu as a dessert.

When asked about physical activity, 78\% of users of Central popular restaurant responded as being mildly physically active, followed by $18 \%$ who reported moderate practice, and 4\% who reported intense physical activity. Again, a similar trend was found for Taquaralto popular restaurant, where $80 \%$ of respondents reported their physical activity as mild, $13 \%$ as moderate, and $7 \%$ as intense. It is a fact that overweight and obesity, as well as sedentary lifestyle, hyperglycemia, and low consumption of fruits are proven risk factors for chronic diseases. This outcome includes one more risk factor to NCDs within users from the popular restaurant programs and highlights the importance of targeted actions on health education based on this information.

In both restaurants (Central and Taquaralto) at least $25 \%$ of the population reported being in possession of NCDs (cardiovascular disease, diabetes, cancer). Araújo et al. [9] found a similar result, where $19.6 \%$ of users of the popular restaurant in Fortaleza/CE (Northeast of Brazil) suffered from chronic diseases. The health profile of users of both restaurants had a significant number of people with one or more risk factors for NCDs which highlights the need to work on preventive actions within those people.

It is a fact that the changing epidemiological profile of Brazil is characterized by the so-called nutritional transition experienced by the country, with the highest burden of NCDs as the consequence of lifestyle changes and globalization and a multi-factorial etiology. However, the mentioned risk factors can be modified, thus preventing the emergence of new cases of chronic diseases. The NCDs are responsible for a significant share of the burden of disease in Brazil, accounting for about $60 \%$ of deaths in the country ${ }^{[14]}$.

According to Malta et al. [15], changing patterns of disease occurrence, along with the increase of NCDs, has imposed new challenges not only for policy makers in the health sector, but also to other governmental agencies whose actions have an impact on these diseases. Still, NCDs are not prevented or managed properly; require medical care that has increasing costs due to the ongoing and necessary technological resources. However, monitoring the prevalence of risk factors for NCDs, mainly behavioral 
The Brazilian Popular Restaurant Program: a user's profile-oriented approach. Abadio Finco e Finco

in nature, such as diet and physical inactivity, is one of surveillance actions. From this action, one may promote a more cost-effective program of health and prevention and the popular restaurants program could be a great instrument to these actions.

It is worthwhile to mention that this discussion and the aim of NCDs prevention are not only in the academic or civil society spheres but it has already been established by governmental institutions nationwide. In the National Health Plan, a Health Agreement of the Brazilian Ministry of Health is stated that:

"The increase in inter-departmental initiatives for prevention and control of major NCDs is a priority. Furthermore, this aspiration takes part not only in the federal level of government but is also exerted by states and municipalities. A foundation of performance in this context is the integrated surveillance of major modifiable risk factors, common to most chronic diseases, namely smoking, unhealthy diet and physical inactivity".

In September 2005, during the National Seminar on Non-communicable Diseases and Health Promotion and with participation of state and municipal managers the National Agenda of NCDs was agreed upon. The National Agenda included three major functions: promoting healthy eating and physical activity practices; the consolidation of the surveillance of diseases and its risk factors in general, both for the general population and vulnerable groups; triggering interventions and strengthening of interdepartmental partnerships for prevention of NCDs.

The nutritional and health profile of popular restaurants' users in Palmas/TO points towards the urgent need for health promotion actions targeted to this group of people following not only the FNS policy designed in Brazil but also international recommendations. The Global Strategy on Diet, Physical Activity and Health urge the need of assist the increase of fruit and vegetables consumption and physical activity promotion all over the world, with especial attention to developing countries as NCDs prevention ${ }^{[16]}$.

Then, we argue why not execute the governmental aims to health improvement and NCDs prevention by its own instruments and use FNS programs such as the popular restaurants to these achieve these accomplishments, indeed? The popular restaurants as a part of a policy for food security and nutrition, which must be integrated into other areas, become public facilities of great importance because they can play an important role in the prevention of NCDs. Thus, popular restaurants would not only have the role of mere food providers, but also act as promoters of health units, a unit for food and nutrition together. And why not dare a bit more, on the basis of these research findings and consider an interface between the popular restaurants and the Brazilian health care system (Sistema Único de Saúde, SUS), where they would play a role in health surveillance with the goal of interacting with centers of primary health care in the city of Palmas. Again, it becomes clear given the health profile of users that there is a need to develop actions for nutritional and health education for the two popular restaurants studied in the city of Palmas in order to prevent the expansion of NCDs and, simultaneously, minimize the risk of injury to those who already have some chronic diseases.

In this context and based on the results presented in the study the need to work on nutrition education among the popular restaurant users becomes evident. This will encourage healthy eating practices, including the usage of lower priced foods at the market, as well as regional foods, demonstrating not only the importance of fruits and vegetables in the diet, but also signaling that a healthy lifestyle involves diet and physical activity, making the popular restaurants a driver for health promotion and reaching the guidelines of the Brazilian Program of Popular Restaurants. It is extremely important to note that throughout the period in which the study was conducted no actions for nutrition education or health promotion were observed in the respective popular restaurants. Therefore, they are not following the premises of the Brazilian Program of Popular Restaurants, which should be performed not only as a mere foodservice, but as FNS space as a whole, i.e. a place where vulnerable people could get not only food, but health within an integrated approach.

From the time that food can be a risk factor for the emergence or aggravation of NCDs and based on the results of the dietary and nutritional profile of program beneficiaries it is of great value to highlight the important role of popular restaurants to act as 
The Brazilian Popular Restaurant Program: a user's profile-oriented approach. Abadio Finco e Finco

food and nutrition units in promoting the health of their guests.

\section{FINAL REMARKS}

The current debate about FNS provides, per se, innovative results, which contribute to the advancement of knowledge in this area. Until recently, there has been no scientific study about the Brazilian Program of popular restaurants, especially in relation to addressing the role of these restaurants as a FNS promotion facility within a health integrated approach.

The present study found that the popular restaurants in Palmas/TO in northern Brazil do not fulfill the main premises of the program, since most users of the restaurants were not considered lowincome individuals. In addition, both restaurants did not develop any action for nutritional education and health promotion, which becomes crucial regarding users who have high risk factors for NCDs (e.g. overweight, low fruit and vegetables consumption).

During the conduct of the study the research team tried to establish a partnership with the Department of Social Services, an agency responsible for the program in the city of Palmas, however, there was no interest by the decision maker. Nevertheless, it is expected that the results obtained in this study, which provide the socioeconomic and health profile of users, serve as an instrument for future actions in the Program of Popular Restaurants of Palmas/TO to ensure that they perform as a FNS and health promotion unit. Such an initiative would benefit the local community and other sectors involved, as well as foster similar studies to be replicated in other regions of the country and even in countries where similar policies are applied. Also, at a FNS program having such an interdisciplinary and inter-sectorial approach, the social participation should be activated and enhanced. This concept is supported and reinforced by the Brazilian Federal law 11.346 enacted on 15th of September of 2006 which creates the National System of Food and Nutrition Security. According to this legislation, the FNS system advocates that is an obligation from public power to respect, protect, promote, inform, monitor, supervise and evaluate the accomplishment to the right of adequate food [1]. In addition, the mechanisms for food rights exigibility should be assured. Surely, the social participation in the formulation, execution, monitoring and control of public policies in all governmental realms should be also ensured. Therefore, the remarks are closed by suggesting the effective social participation either by the creation of a specific committee composed by members of different institutions from the civil society or even the inclusion of the already existing FNS municipal and state boards to take part in the management of such an important tool of FNS as the popular restaurants. The social participation would lead the program to achieve its integrative role as originally designed in its conception.

\section{REFERENCES}

[1] Brasil. Lei no 11.346, de 15 de setembro de 2006. Cria o Sistema Nacional de Segurança Alimentar e Nutricional SISAN, com vistas a assegurar o direito humano à alimentação adequada e dá outras providências. Diário Oficial da União, Brasília, 18 set. 2006. Seção 1, p. 1.

[2] II National Conference on Food and Nutrition Security/Final Report Olinda (PE), Brazil, 2004, 17 a 20 de março de 2004.

[3] Gil AC. Gil AC. Métodos e técnicas de pesquisa social. São Paulo: Editora Atlas S.A.; 1995.

[4] Ribeiro AC, Salvio KEO, Rodrigues MdLCF, Costa THMd, Schmitz BdAS. Validação de um questionário de frequência de consumo alimentar para população adulta. Rev Nutr. 2006;19(5):553-62.

[5] Liu C, Xie B, Chou C-P, Koprowski C, Zhou D, Palmer $\mathrm{P}$, et al. Perceived stress, depression and food consumption frequency in the college students of China seven cities. Physiology \& Behavior. 2007;92(4):748-54.

[6] Gordon CC, Chumlea WC, Roche AF. Stature, recumbent length, and weight. In: Lohman TG, Roche AF, Martorell R, editors. Anthropometric Standardization Reference Manual. Champaign, Illinois: Human Kinetics Books; 1988. p. 3-8.

[7] Food and Agriculture Organization. Human Energy Requirements. Report of a joint FAO/WHO/UNU. Expert Consultation. Rome; 2004.

[8] Brasil. Lei no 11.498, de 28 de junho de 2007. Dispõe sobre o salário mínimo a partir de 1 o de abril de 2007 e revoga a Lei no 11.321, de 7 de julho de 2006. Diário Oficial da União, Brasília, 29 jun. 2007. Seção 1, p. 2.

[9] Araújo FALVd, Almeida MI, Bastos VC. Aspectos alimentares e nutricionais dos usuários do "restaurante popular Mesa do Povo". Saude Soc. 2007;16(1):117-33. 
The Brazilian Popular Restaurant Program: a user’s profile-oriented approach. Abadio Finco e Finco

[10] Willet WC. Nutritional epidemiology. 2nd ed. New York: Oxford University Press; 1998.

[11] Brasil. Decreto no 6.135, de 26 de junho de 2007. Dispõe sobre o Cadastro Único para Programas Sociais do Governo Federal e dá outras providências. Diário Oficial da União, Brasília, 27 jun. 2007. Seção 1, p. 3.

[12] Popkin BM. The nutrition transition and obesity in the developing world. J Nutr. 2001;131(3):871S-3S.

[13] Mariath AB, Grillo LP, Silva RO, Schmitz P, Campos IC, Medina JRP, et al. Obesidade e fatores de risco para o desenvolvimento de doenças crônicas não transmissíveis entre usuários de unidade de alimentação e nutrição. Cadernos de Saúde Pública. 2007;23(4):897-905.

[14] Yokota RTdC, Vasconcelos TFd, Ito MK, SaidDutra E, Baiocchi KC, Hamann EM, et al. Prevalence of risk factors for chronic diseases in two regions of Distrito Federal. Comun Ciênc Saúde. 2007;18(4):289-96.

[15] Malta DC, Cezário AC, Moura Ld, Morais Neto OLd, Silva Junior JBd. A construção da vigilância e prevenção das doenças crônicas não transmissíveis no contexto do Sistema Único de Saúde. Epidemiol Serv Saude. 2006;15(3):47-65.

[16] World Health Organization. Global strategy on diet, physical activity and health. Geneva: WHO; 2004. 